\title{
Discretionary monetary policy, quantitative easing, and the decline in US labor share
}

\author{
Eric Olson • Andrew T. Young* \\ Department of Economics, West Virginia University, USA
}

Received: 15 April 2015

Revised: 28 June 2015

Accepted: 29 June 2015

\begin{abstract}
Since the turn of the millenium, labor shares of income in the US and other OECD countries have been declining (OECD, 2012; Elsby et al., 2013). Piketty's (2014) influential book has drawn attention to this decline in labor shares and has argued that it may be an inevitability that is inherent in capitalist economies. Other authors have argued that globalization may be a cause (Harrison, 2005; Guscina, 2006; Schneider, 2011). In this note we explore the possibility that in the US discretionary monetary expansion has played a role. Limited participation and Cantillon effects may lead to a transfer of income from providers of labor services to owners of capital. We estimate the relationship between monetary policy innovations and labor share based using VARs containing federal funds rate changes, monetary base growth, or the principle component of a set of monetary/interest rate variables. VARs are estimated separately for the 1986-2002 (rule-based), 2003-2014 (discretionary), and 2008Q3-2014 (quantitative easing). We report that positive monetary policy innovations are associated with statistically significant, persistent decreases in labor shares in the later (discretionary and quantitative easing) periods.
\end{abstract}

Keywords: labor share, monetary policy, income distribution, quantitative easing, Great Transfer

JEL Classification Codes: E52, E40, E25, D33

\section{Introduction}

Since the turn of the millennium, US labor share has been on average declining. This is true regardless of whether one considers compensation of employees as a share of GDP or gross domestic income (GDI); also regardless of whether or not proprietors' income is excluded from the aggregate income (Figure 1). Similar declines have been observed throughout OECD countries (OECD, 2012; Elsby et al., 2013).

\footnotetext{
*Corresponding author. E-mail: Andrew.Young@mail.wvu.edu.
}

Citation: Olson, E. and Young, A.T. (2015) Discretionary monetary policy, quantitative easing, and the decline in US labor share, Economics and Business Letters, 4(2), 63-78. 
Piketty's (2014) influential book has drawn increased attention to these declines in labor shares. He argues that they may be an inevitable outcome for capitalist economies. Relatedly, Harrison (2005), Guscina (2006), and Schneider (2011) argue that globalization may be a root cause of the decline in labor shares. Consistent with these studies, Elsby et al (2013) documents that declines in US labor share are linked to reductions in payroll compensation, a likely cause of which is the off-shoring of the labor intensive part of the US supply chain. ${ }^{1}$ Alternatively, Young and Lawson (2014) present evidence that more economically free countries have higher labor shares, all else equal. Also, Sorokina and Young (2015) find that while trade as a share of GDP may be narrowly associated with lower labor shares, some measures of social globalization (e.g., international mobility of individuals and cultural openness) are positively related to labor shares.

In the US case, labor share appears to have plateaued around 2005-2006, only to begin declining again in the aftermath of the 2008 financial markets crisis and the Great Recession. Motivated by the timing of both the initial decline and the resumption of the decline postGreat Recession, we empirically examines the role of monetary policy in general, and discretionary monetary policy in particular, in US labor share determination. ${ }^{2}$

Models of limited participation have been widely employed to account for the short-run neutrality of money (e.g., Lucas, 1990; Fuerst, 1992; Christiano and Eichenbaum, 1995, Williamson, 2006). When the Fed conducts monetary policy, "economic agents on the receiving end of [the] transaction typically are large financial institutions that are not directly connect to all other economic agents through exchange" (Williamson, 2005, p. 2). Monetary policy can thus affect nominal reserves in the banking system without a contemporaneous effect on the nominal prices of goods, leading to short-run changes in real interest rates.

We posit that limited participation can also be associated with Cantillon-type effects. Financial institutions and the firms that they (primarily) lend to can benefit at the expense of other economic agents. In the case of monetary expansion, capital receives the new money before labor and prior to economy-wide inflation. ${ }^{3}$ Alternatively, Alcalá and Sancho (2000) present a model with monopolistic competition but without limited participation where inflation is positively related to labor share. Intuitively, $(\mathrm{S}, \mathrm{s})$-pricing rules imply that higher steady-state inflation increases competition (i.e., it widens price dispersion across firms) and decreases profits relative to wages. Given these competing alternatives, the question of what effect monetary innovations have on labor share is ultimately an empirical one.

Cantillon-type effects may be particularly important in the presence of labor market frictions. Christiano and Eichenbaum (1995) demonstrate that limited participation effects are amplified when past employment decisions constrain present ones. More generally, papers by Zanetti (20007), Trigari (2009), Christiano et al. (2013) demonstrate that the effect of monetary policy on labor markets differs in important ways from the standard New Keynesian model when labor market frictions are present.

We estimate the relationship between monetary policy innovations and labor share. Estimations are conducted separately for the 1986-2002 (rule-based), 2003-2014 (discretionary), and 2008Q3-2014 (quantitative easing) time periods. This distinction between time periods is motivated, first, by Taylor's (2009) argument that Fed policy is best characterized as rule-based through 2002 but then "gets off track" (i.e., becomes discretionary

\footnotetext{
${ }^{1}$ Elsby et al. (2013) also find that, at the industry-level, there is a positive relationship between union membership and labor share. However, the estimated relationship is statistically insignificant and small. Also at the US industry level, Young and Zuleta (forthcoming) report that any positive relationship between unions and labor share is actually to be found in services rather than manufacturing. Both of these studies cast doubt on the relevance of de-unionization for the decline in US labor share.

${ }^{2}$ Rudd and Whelan (2002) put forth the proposal that monetary policy actually targets labor share.

${ }^{3}$ Monnin (2014) has suggested this sort of Cantillon effect channel for monetary policy to affect labor share, though his analysis focuses on the share of income received by the top $10 \%$ of wage earners.
} 
and overly loose). Second, following the financial market crisis, we characterize post-2008 as the quantitative easing (QE) and are particularly interested how monetary policy may have affected labor share given the focus on large increases in reserves and the purchases of nontraditional (non-Treasury) assets.

In vector autoregressions (VARs) we consider changes in the monetary base and also the federal funds rate as indicators of monetary policy. During much of the QE period the federal funds target remained constant at the zero lower bound, so for 2008Q3-2014 we employ, instead of a VAR with the federal funds rate, the factor-augmented vector autoregressive (FAVAR) approach proposed by Bernanke et al. (2005). Employing the FAVAR approach, we estimate the effect on labor share of the principal component of monetary, reserve, and loan variables suggested by McCracken and Ng (2014).

\section{Data and methodology}

To examine the relationship between monetary policy and labor share, we obtain quarterly data from the St. Louis Federal Reserve's FRED database. Our measure of labor share is calculated by dividing compensation to employees by GDP (both seasonally adjusted).

We employ three different indicators of monetary policy: (i) the federal funds rate, (ii) the (adjusted St. Louis) monetary base, and (iii) the principal component of 8 monetary variables. The federal funds rate has been the Fed's target rate during the entire 1986-2014 time period. The monetary base provides an additional indicator of the stance of monetary policy, speaking directly to the amount of reserves being created, and will also be informative regarding the stance of monetary policy when the target federal funds rate is at the zero lower bound (characteristic of much of the QE period, 2008Q3-2014). Finally, since the QE period is characterized by purchases of a range of non-traditional assets as well as an enhanced emphasis on forward guidance, we estimate an FAVAR based on innovations to the principal component of a number of different monetary, reserve, and loan variables.

In order to obtain impulse response functions we estimate the following bivariate VAR:

$$
X_{t}=A_{0}+B(L) X_{t-p}+e_{t}
$$

where $\mathrm{B}(\mathrm{L})$ is a lag polynomial and $\mathbf{X}_{\mathbf{t}}$ is a vector that contains one of the above monetary policy variables and labor share of GDP. As a preliminary, we test each of our variables for a unit root. Each variable (with the exception of the monetary policy principal component) contains a unit root. ${ }^{4}$ As such, we estimate (1) including the variables in first differences (log differences for the monetary base) rather than levels such that

$$
\Delta \mathrm{X}_{\mathrm{t}}=\mathrm{A}_{0}+\mathrm{B}(\mathrm{L}) \Delta \mathrm{X}_{\mathrm{t}-\mathrm{p}}+\mathrm{e}_{\mathrm{t}} .
$$

The lag length for each VAR for each sample period is selected using the AIC. In order to identify the shocks in (2), we implement a Choleski decomposition. In particular, we order the variables such that the monetary policy variable is ordered prior to labor share. This amounts to assuming that a monetary policy shock may have a contemporaneous effect on labor share but that a shock to labor share has no contemporaneous effect on monetary policy. ${ }^{5}$

\footnotetext{
${ }^{4}$ We used ADF and ERS unit root tests. Results may be obtained upon request.

${ }^{5}$ As a robustness check we reversed the ordering in (2). The results did not qualitatively change.
} 


\section{Results}

In this section we report impulse responses and the results of Granger causality tests for each of the sample periods: 1986-2002 (rule-based), 2003-2014 (discretionary), and 2008Q3$2014(Q E)$.

\subsection{Rule based monetary policy (1986-2002)}

Figures $2 \& 3$ display the impulse responses from estimating (2) using the federal funds rate and the monetary base, respectively, as policy variables along with bootstrapped standard error bands.

The rows in Figures $2 \& 3$ display the standardized cumulative responses from a one standard deviation shock in column variable. During rule-based monetary policy, shocks to neither monetary policy variable have statistically significant effects on labor share after 12 quarters. The federal funds rate effect is essentially zero for the entire 12 quarters. A monetary base shock, alternatively, does have a small contemporaneous negative (-0.1 standard deviations) effect on labor share. However, after 3 quarters the effect is no longer statistically significant.

Table 1 reports Granger causality tests from using the federal funds rate as the monetary policy variable (Panel A) and then using the monetary base (Panel B).

The Table is displayed such that the row variables Granger cause those listed in the columns. Consistent with Figures $2 \& 3$, each variable Granger causes itself at the $\leq 5 \%$ significance level; interestingly the monetary base Granger causes labor share at the $1 \%$ significance level.

\subsection{Discretionary monetary policy (2003-2014)}

Figures $4 \& 5$ display the standardized cumulative impulses responses from estimating (2) over the 2003-2014 (discretionary) time period.

In contrast to the rule-based time period, to the Federal Funds Rate during the discretionary monetary policy period are associated with a statistically significant 0.35 standard deviation increase in labor share after 12 quarters. Likewise, as displayed in Figure 5, shocks to the monetary base induce a statistically significant 0.25 standard deviation reduction in labor share after 12 quarters.

Somewhat surprisingly, a change in the labor share of GDP has a statistically significant and positive effect on both the Federal Funds rate as well as the monetary base. Table 2 displays the Granger causality tests from estimating (2) over the 2003-2014 time period for both the Federal Funds rate as well as the monetary base.

As can be seen in both Panel A as well as Panel B, both measures of monetary policy Granger cause labor share at the 5\% significance level. Labor share of GDP does Granger causes federal funds rate but not the monetary base at the $5 \%$ significance level. ${ }^{6}$

\footnotetext{
${ }^{6}$ We also estimated VARs analogous to those underlying the Figures 4 and 5 results that additionally contained output growth and inflation. Doing so estimates 36 parameters using 47 time series observations, so we are cautious in drawing inferences. Notwithstanding that concern, the estimated impulse responses of monetary policy on labor share are qualitatively consistent with those reported in Figures 4 and 5. (These results are available from the authors upon request) Over the horizons considered, in those VARs inflation shocks have no (federal funds) or a positive (monetary base) estimated effect on labor share. This suggests that the negative effect on expansionary monetary policy on labor share is not working through a positive inflation effect on markups (which would be the case in a standard New Keynesian model with sticky prices).
} 


\subsection{Unconventional monetary policy (2008 - 2014)}

Due to the Federal Reserve's unconventional monetary policy and the target Federal Funds rate staying at 0.25 basis points since late 2008, we chose to drop the Federal Funds rate as our monetary policy variable. While changes in the St. Louis monetary base capture the effects of the Federal Reserve's quantitative easing programs, the changes in the monetary base do not capture the forward guidance and "open mouth operations" that policy makers at the Federal Reserve implemented in addition to the large scale purchase programs. To address this concern, we extract a principle component time series from the monetary, reserve, and loan variables in McCracken and $\mathrm{Ng}$ (2014) to extract a principal component. Our expectation is that this principal component captures some of the forward guidance and other aspects of the unconventional monetary policy that followed the financial markets crisis.

We chose third quarter of 2008 as our start date because of the unconventional programs implemented by the Federal Reserve and US Treasury department in response to the failures of Lehman Brothers, AIG, and Fannie Mae and Freddie Mac. Thus, our QE period spans the 2008Q3-2014Q4 time period. Due to the reduced number of observations in our sample period, we demeaned and standardized each of the variables used in the VAR. As such, (2) becomes

$$
\Delta \mathrm{X}_{\mathrm{t}}=\mathrm{B}(\mathrm{L}) \Delta \mathrm{X}_{\mathrm{t}-\mathrm{p}}+\mathrm{e}_{\mathrm{t}}
$$

which reduces the number of parameters to estimate. Again, a lag length of $p=2$ was selected using the AIC. ${ }^{7}$ Figures $6 \& 7$ displays the standardized cumulative impulse responses, along with bootstrapped confidence intervals, from estimating (3).

Similar to the results in Figures $4 \& 5$, a shock in the monetary base induces a statistically significant 0.30 standard deviation reduction in labor share after 12 quarters. Similar to Figure 6 , using the monetary principal component as our measure of monetary policy, a one standard deviation shock in the monetary policy principal component induces a 0.25 standard deviation reduction in labor share. Table 3 displays the Granger causality tests over the QE period.

As can be seen in Panel A of Table 3, each of the variables Granger cause themselves and changes in the monetary base Granger cause changes in labor share at the $1 \%$ significance level. Somewhat surprisingly, changes in labor share Granger cause the changes in the monetary policy principal component whereas the monetary policy principal component does not Granger cause changes in the labor share of GDP.

\section{Discussion}

Does expansionary monetary policy contribute to declines in labor share of GDP? If financial institutions and the firms to which they lend participate in monetary expansions prior to employees, then resources may be redistributed into profits at the expense of compensation to employees. This effect may be more pronounced when monetary policy is discretionary. To the extent that monetary policy is difficult to correctly anticipate, it will be reflected less in the bargaining and contracting of economic agents.

We have presented evidence above that is consistent with discretionary US monetary policy shocks having negative effects on labor share. In particular, during the 2003-2014 period, innovations to the monetary base are associated with persistent, statistically significant, negative effects on labor share. After 3 years a positive monetary base shock is associated with a decline in labor share of about 0.25-0.30 standard deviations. Alternatively, during the period when monetary policy is better characterized as rule-based (1986-2002) period, when monetary policy is better characterized as rule-based, we report, at most,

\footnotetext{
${ }^{7}$ The resulting lag length selection resulted in 8 parameters estimated using 25 observations.
} 
transient (3 quarter) effects on labor share. Our results suggest that the increased role for monetary policymaker discretion associated with the financial market crisis and Great Recession may indeed have played a role in the decline in US labor share.

Acknowledgements. We would like to thank the editor and referees for the helpful comments and suggestions.

\section{References}

Bernanke, B.S., Boivin, J. and Eliasz, P. (2005) Measuring the effects of monetary policy: a factor-augmented vector autoregressive (FAVAR) approach, Quarterly Journal of Economics, 120, 387-422.

Christiano, L.J. and Eichenbaum, M. (1995) Liquidity effects, monetary policy, and the business cycle, Journal of Money, Credit and Banking, 27, 1113-1136.

Christiano, L.J., Eichenbaum, M.S. and Trabandt, M. (2013) Unemployment and business cycles, NBER Working Paper 19265. (http://www.nber.org/papers/w19265.pdf).

Elsby, M.W., Hobijn, B. and Şahin, A. (2013) The decline of the U.S. labor share, Brookings Papers on Economic Activity, Fall, 1-52.

Guscina, A. (2006) Effects of globalization on labor's share in national income, IMF Working Paper WP/06/294.

(https://www.imf.org/external/pubs/ft/wp/2006/wp06294.pdf).

Fuerst, T.S. (1992) Liquidity, loanable funds, and real activity, Journal of Monetary Economics, 29, 3-24.

Harrison, A.E. (2005) Has globalization eroded labor's share? Some cross-country evidence, Working Paper. (http://mpra.ub.uni-muenchen.de/39649/1/MPRA_paper_39649.pdf).

Lucas, R.E. (1990) Liquidity and interest rates, Journal of Economic Theory, 50, 237-264.

McCracken, M. and Ng, S. (2014) FRED-MD: a monthly database for macroeconomic Research, Working Paper (http://www.columbia.edu/ sn2294/papers/freddata.pdf).

Monnin, P. (2014) Inflation and income inequality in developed economies, CEP Working Paper 2014/1. (http://www.cepweb.org/wpcontent/uploads/2014/05/CEP_WP_Inflation_and_Income_Inequality.pdf).

OECD (2012) Labour losing to capital: what explains the declining labor share?, OECD Employment Outlook 2012, OECD.

Piketty, T. (2014) Capital in the Twenty-First Century, Cambridge: Cambridge University Press.

Rudd, J. and Whelan, K. (2002) Should monetary policy target labor's share of income?, Federal Reserve Bank of Francisco Proceedings.

Schneider, D. (2011) Bargaining, openness, and the labor share, Working Paper. (http://sfb649.wiwi.hu-berlin.de/papers/pdf/SFB649DP2011-068.pdf).

Sorokina, M. and Young, A.T. (2015) Has globalization actually caused the decline in labor shares?, Working Paper.

Taylor, J.B. (2009) Getting off track: how government actions and interventions caused, prolonged, and worsened the financial crisis, Hoover Institution, Stanford.

Trigari, A. (2009) Equilibrium unemployment, job flows, and inflation dynamics, Journal of Money, Credit and Banking, 41, 1-33.

Williamson, S.D. (2005) Limited participation and the neutrality of money, Federal Reserve 
Bank of Richmond Economic Quarterly, 91, 1-20.

Williamson, S.D. (2006) Search, limited participation, and monetary policy, International Economic Review, 47, 107-128.

Young, A.T. and Lawson, R.A. (2014) Capitalism and labor shares: a cross-country panel study, European Journal of Political Economy, 33, 20-36.

Young, A.T. and Zuleta, H. (2015) Do unions increase labor shares? Evidence from US industry-level data, Eastern Economic Journal, forthcoming.

Zanetti, F. (2007) A non-Walrasian labor market in a monetary model of the business cycle, Journal of Economic Dynamics and Control, 31, 2413-2437. 
Table 1. Granger Causality Tests

\begin{tabular}{c|c|c|}
\hline \hline $\begin{array}{c}\text { Panel A: } 1986-2002 \\
\text { (Row Variable Granger Cause Column) }\end{array}$ & Federal Funds Rate & Labor Share of GDP \\
\hline \hline \hline Federal Funds Rate & $190.196^{* * *}$ & 0.10 \\
\hline Labor Share of GDP & 0.3553 & $3.41^{* *}$ \\
\hline \hline
\end{tabular}

Panel B: 1986 - 2002

(Row Variable Granger Cause Column) Monetary Base Labor Share of GDP

\begin{tabular}{|c|c|c|}
\hline \hline Monetary Base & $136.49^{* * *}$ & $6.69^{* * *}$ \\
\hline Labor Share of GDP & 0.14 & $3.49^{* *}$ \\
\hline \hline
\end{tabular}

Table 2. Granger Causality Test

\begin{tabular}{c|c|c|}
\hline \hline $\begin{array}{c}\text { Panel A: 2002 - 2014 } \\
\text { (Row Variable Granger Cause Column) }\end{array}$ & Federal Funds Rate & Labor Share of GDP \\
\hline \hline Federal Funds Rate & $249.20^{* * *}$ & $3.97^{* *}$ \\
\hline Labor Share of GDP & $9.96^{* *}$ & $13.09^{* * *}$ \\
\hline \hline $\begin{array}{c}\text { Panel B: } 2002-2014 \\
\text { (Row Variable Granger Cause Column) }\end{array}$ & Monetary Base & Labor Share of GDP \\
\hline \hline Monetary Base & $86.08^{* * *}$ & $3.20^{* *}$ \\
\hline Labor Share of GDP & 1.91 & $12.01^{* * *}$ \\
\hline \hline
\end{tabular}


Table 3. Granger Causality Test

\begin{tabular}{c|c|c|}
\hline \hline $\begin{array}{c}\text { Panel A: 2009 - 2014 } \\
\text { (Row Variable Granger Cause Column) }\end{array}$ & Monetary Base & Labor Share of GDP \\
\hline \hline Monetary Base & $43.00^{* * *}$ & $4.63^{* *}$ \\
\hline Labor Share of GDP & 1.00 & $13.25^{* * *}$ \\
\hline \hline & & Labor Share of GDP \\
$\begin{array}{c}\text { Panel B: } 2009-2014 \\
\text { (Row Variable Granger Cause Column) }\end{array}$ & Monetary PC & 2.06 \\
\hline \hline Monetary PC & 0.96 & $5.99^{* *}$ \\
\hline \hline
\end{tabular}


Figure 1. US Labor Share Measures - Quarterly, 1982.3-2014.3

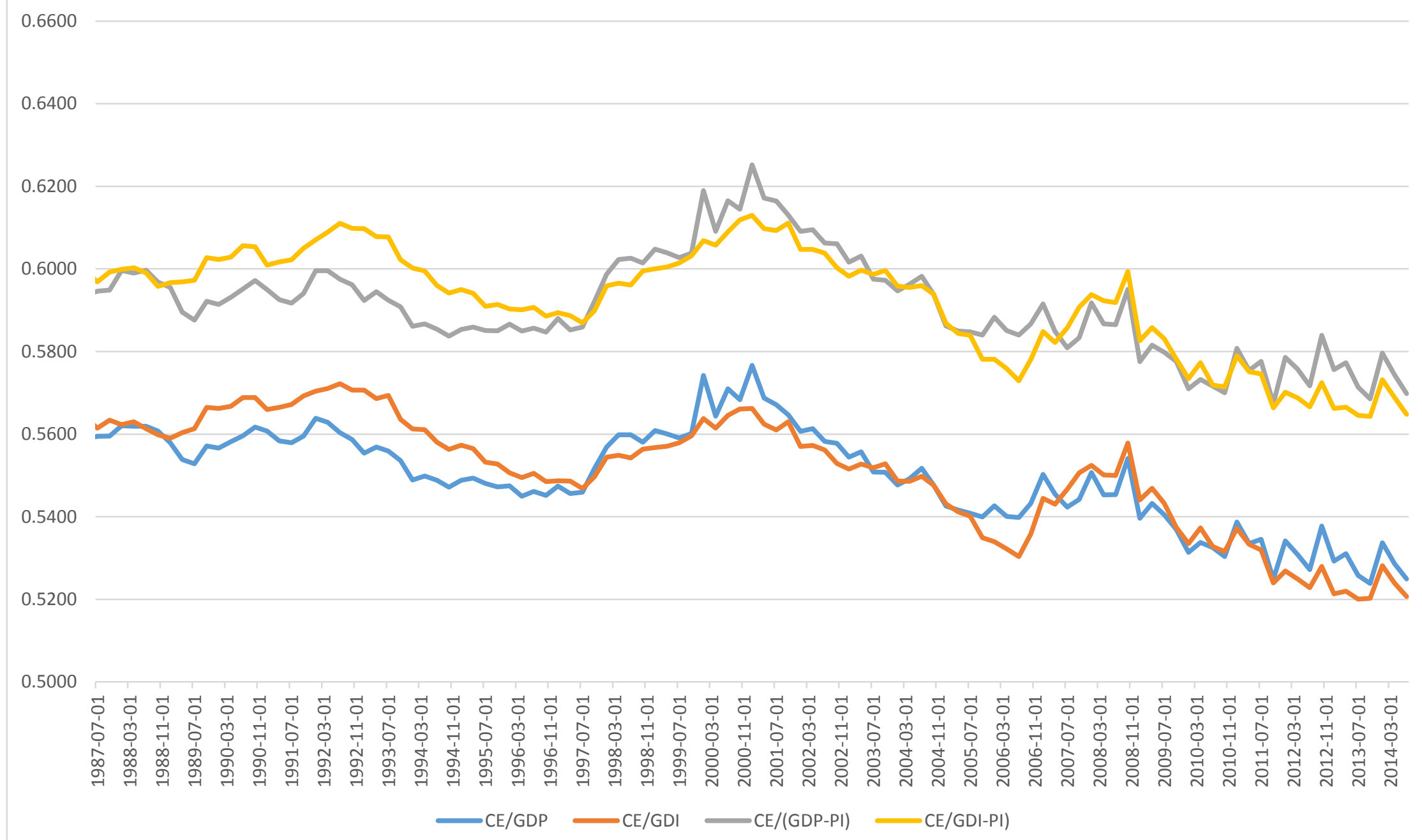

Note: "CE" is compensation for employees; "GDP" is gross domestic product; "GDI" is gross domestic income; "PI" is proprietors' income. All data are obtained from the St. Louis Federal Reserve FRED database and originally from the US Bureau of Economic Analysis (BEA). 
Figure 2. Cumulative Impulse Responses (Federal Funds Rate): 1986 - 2002

Federal Funds Rate

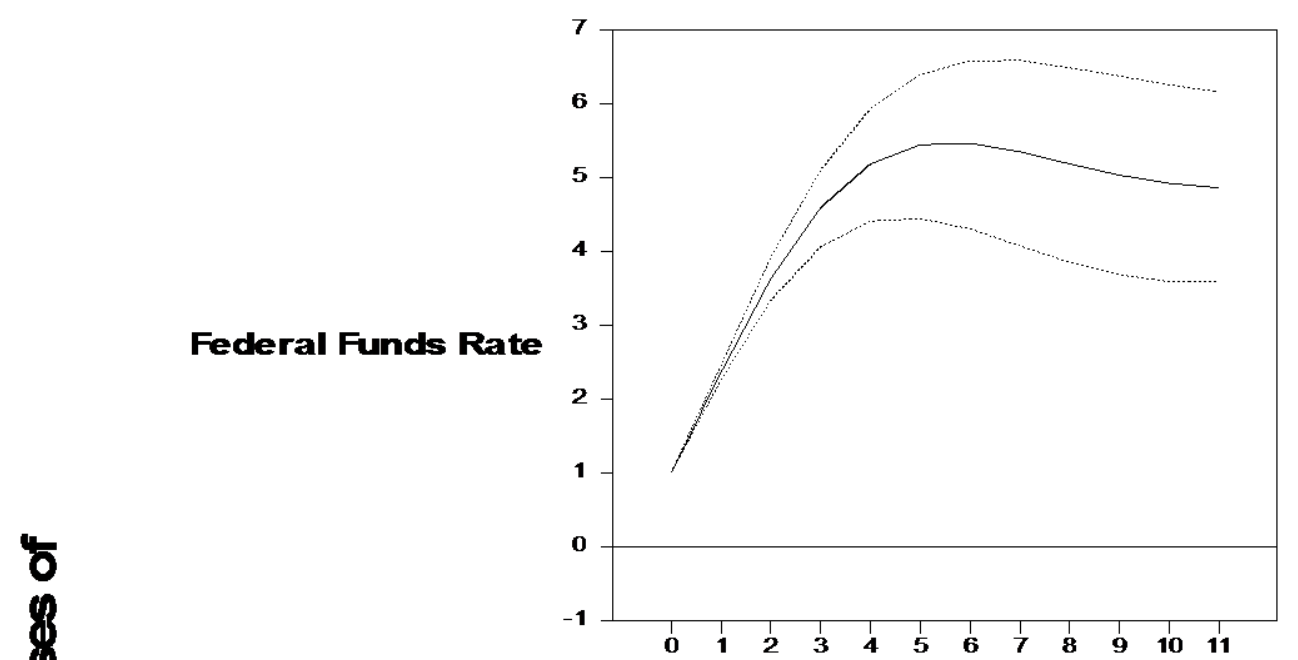

$\frac{8}{8}$

Changes in Labor Share

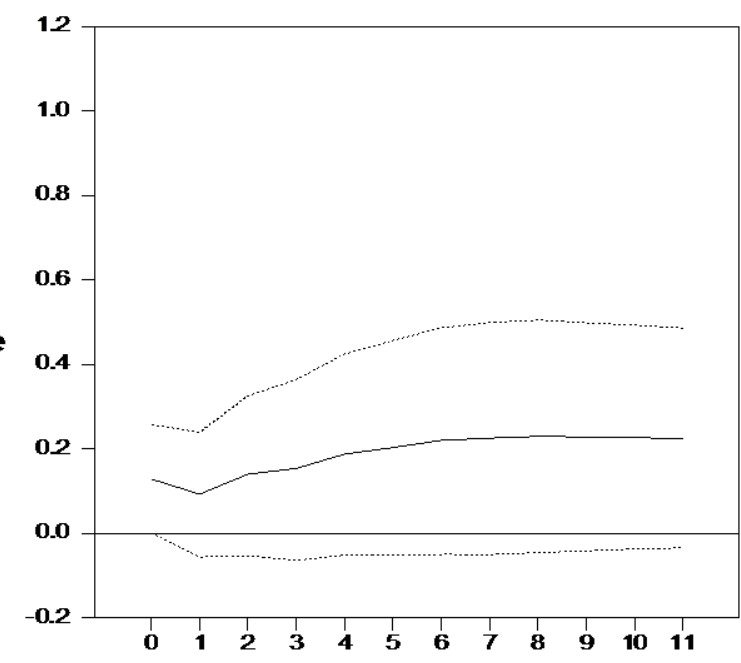

Changes in Labor Share
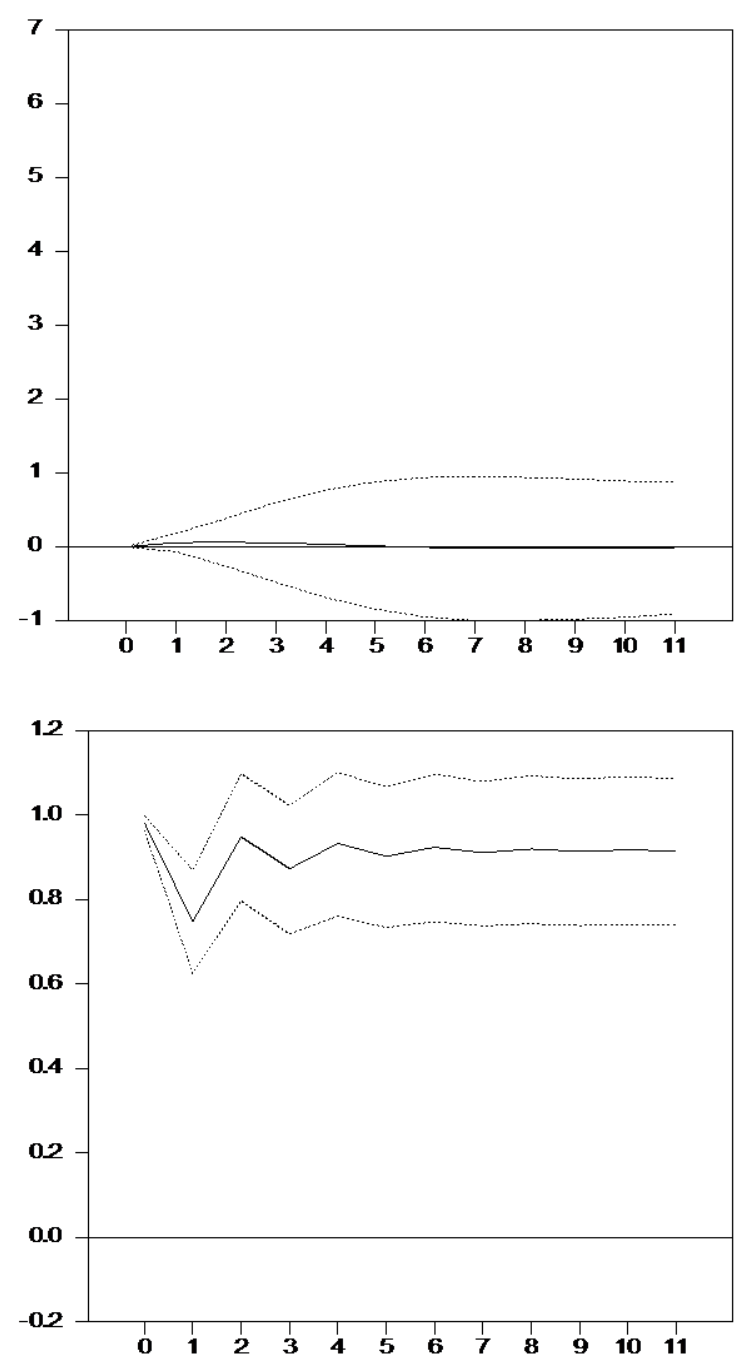
Figure 3. Cumulative Impulse Responses (Monetary Base): 1986 - 2002
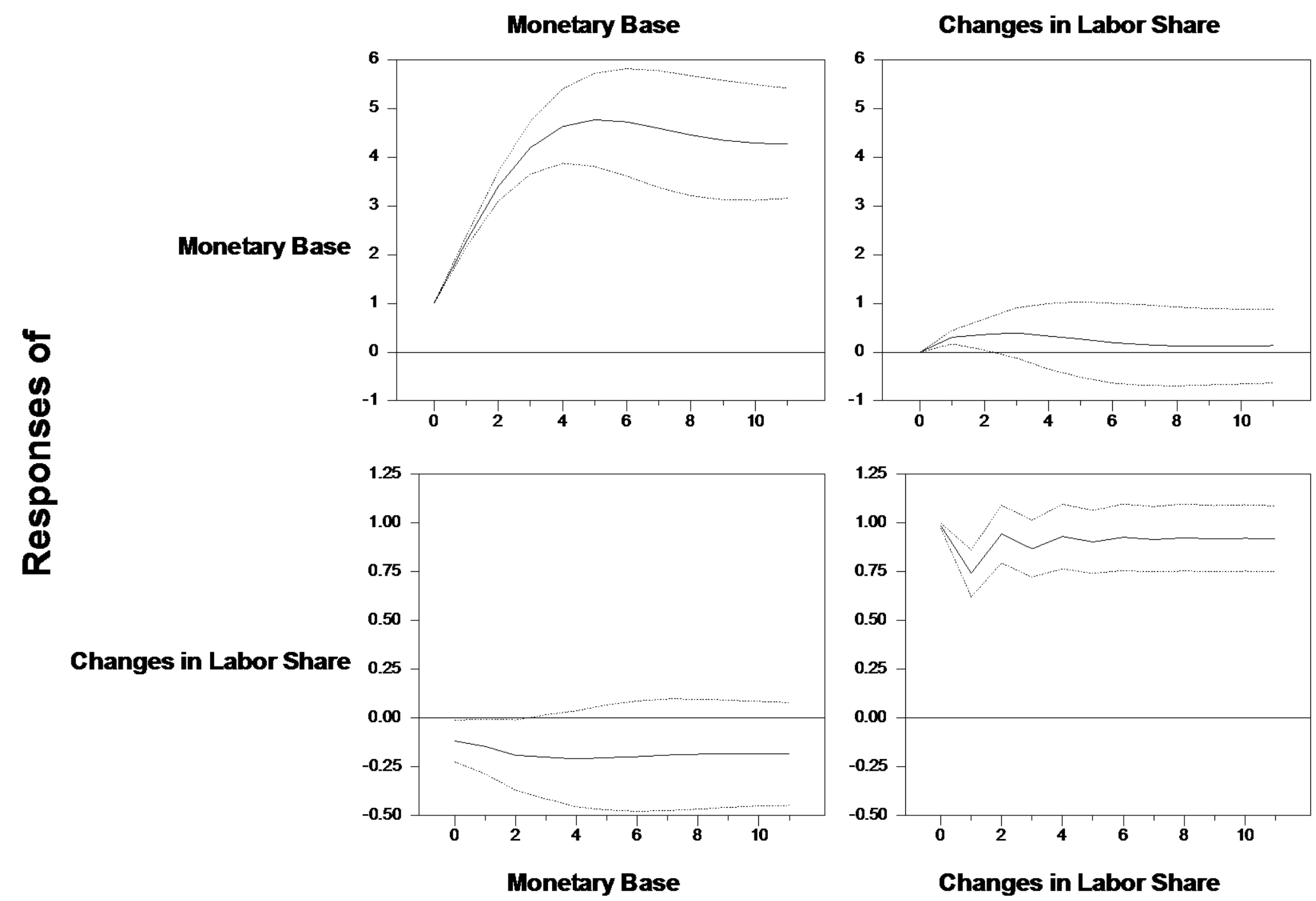
Figure 4. Cumulative Impulse Responses (Federal Funds Rate) 2003 - 2014

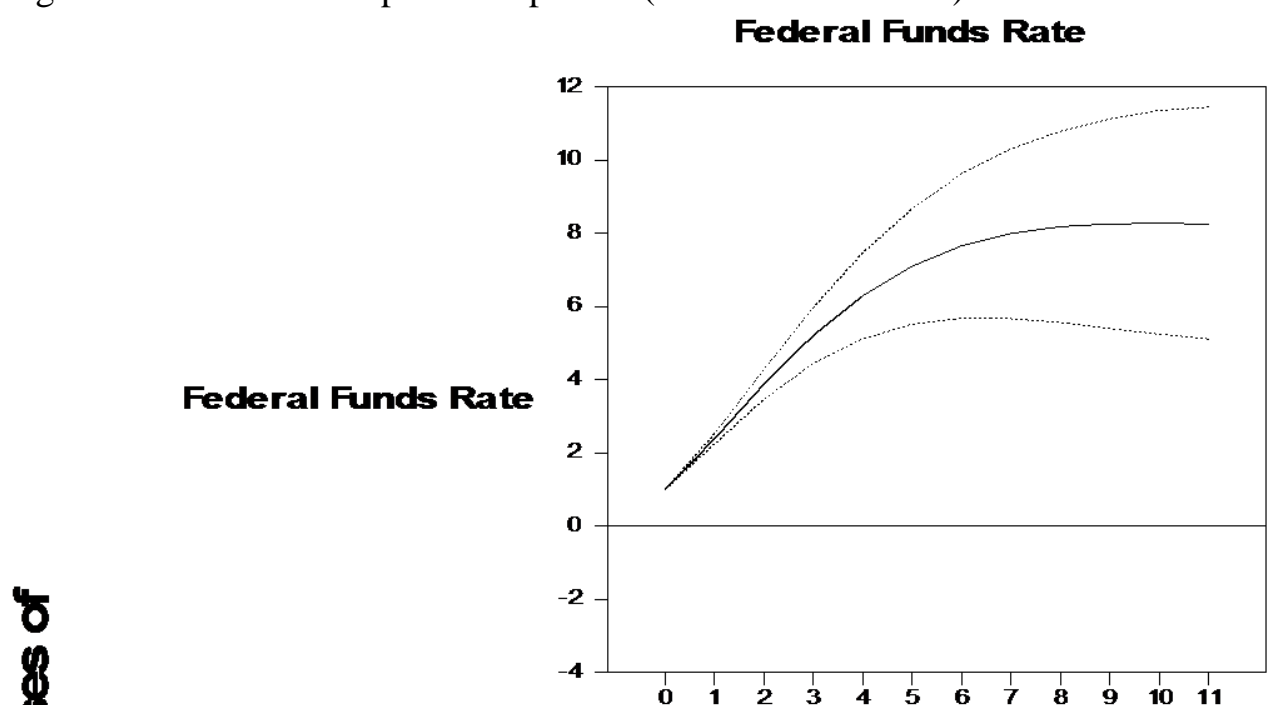

8

$\frac{8}{8}$

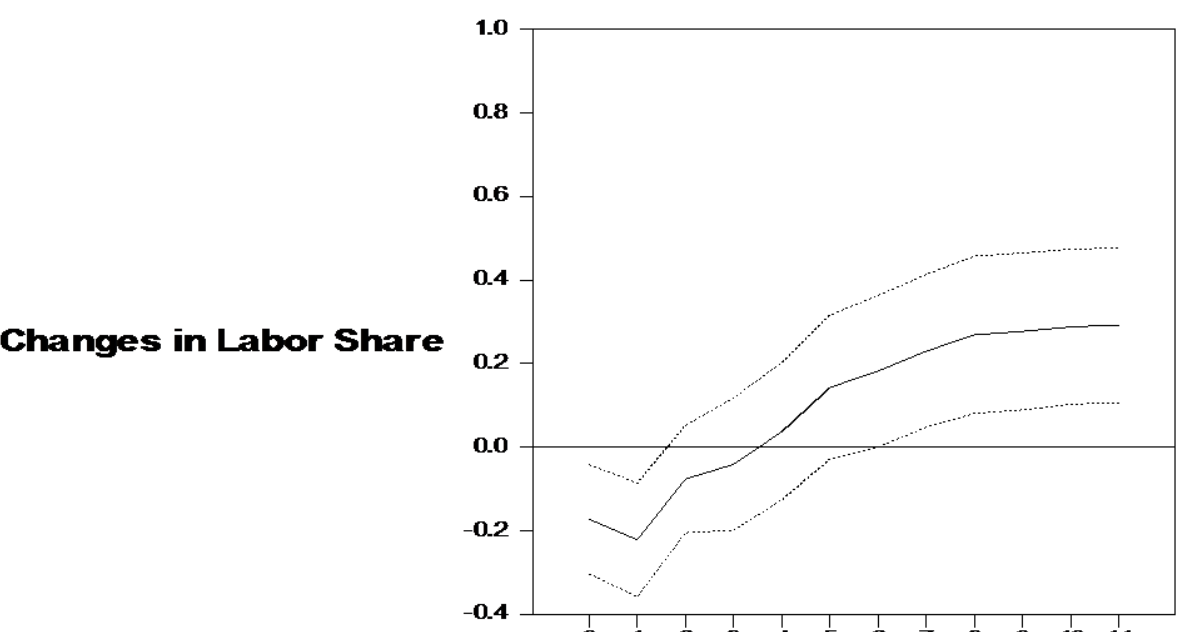

Changes in Labor Share
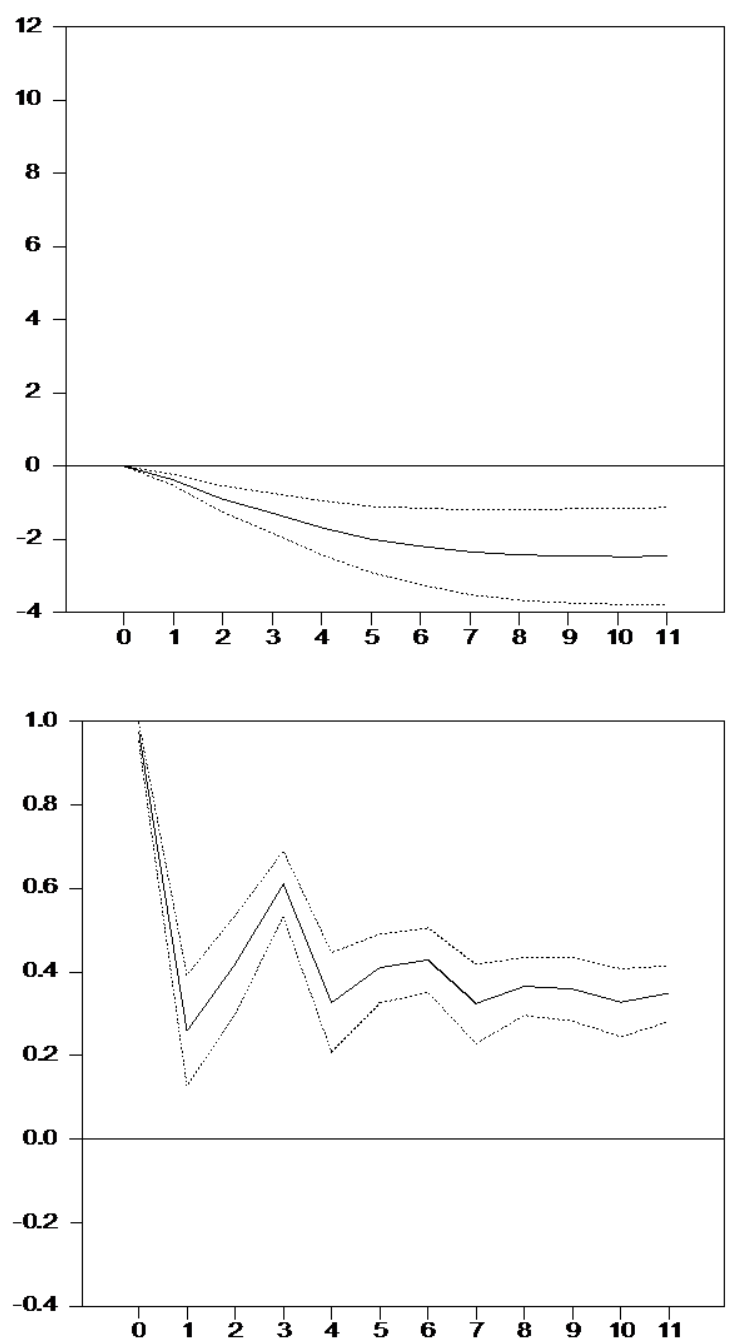
Figure 5. Cumulative Impulse Responses (Monetary Base) 2003 - 2014
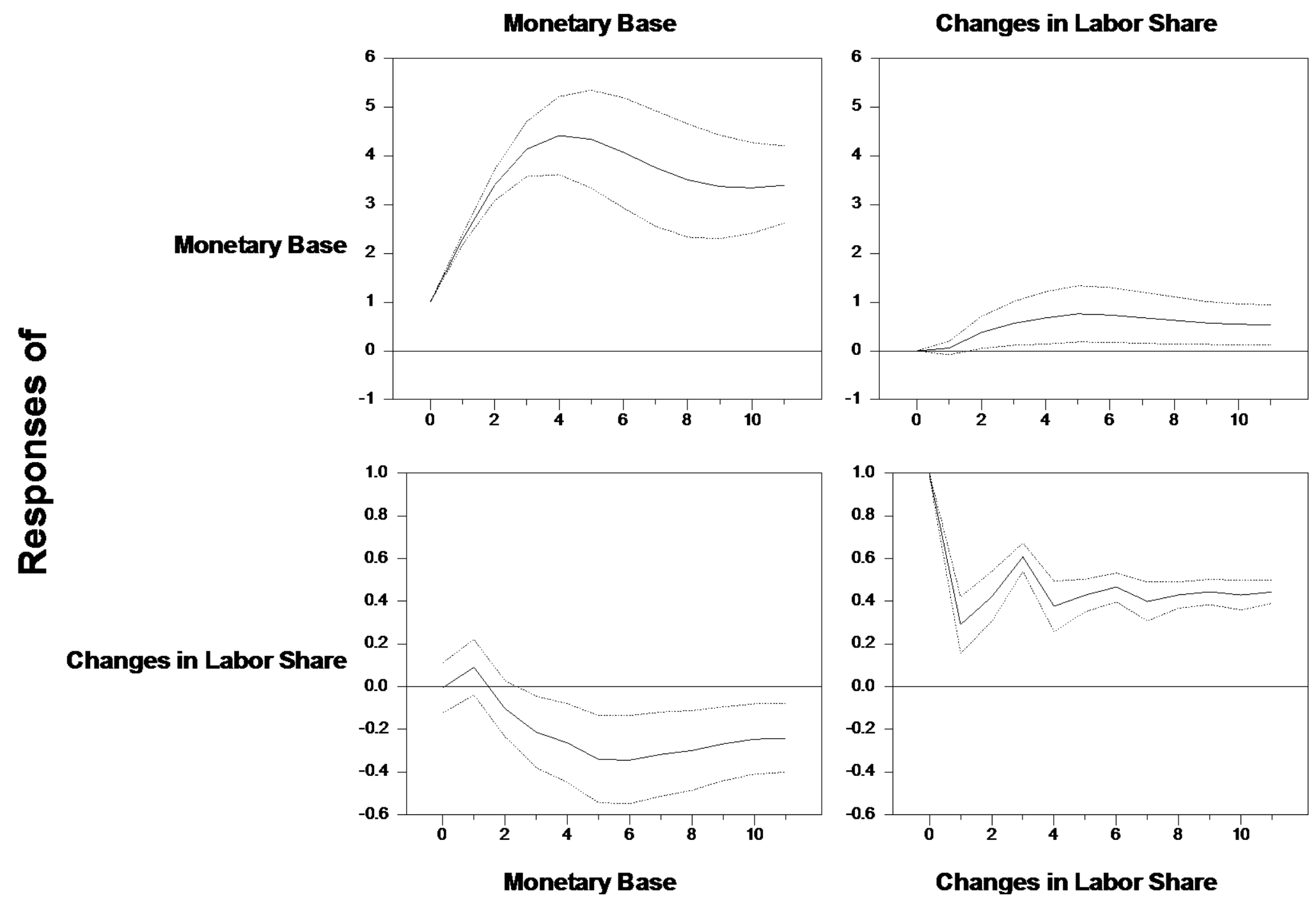
Figure 6. Cumulative Impulse Responses (Monetary Base) 2008:Q3 - 2014
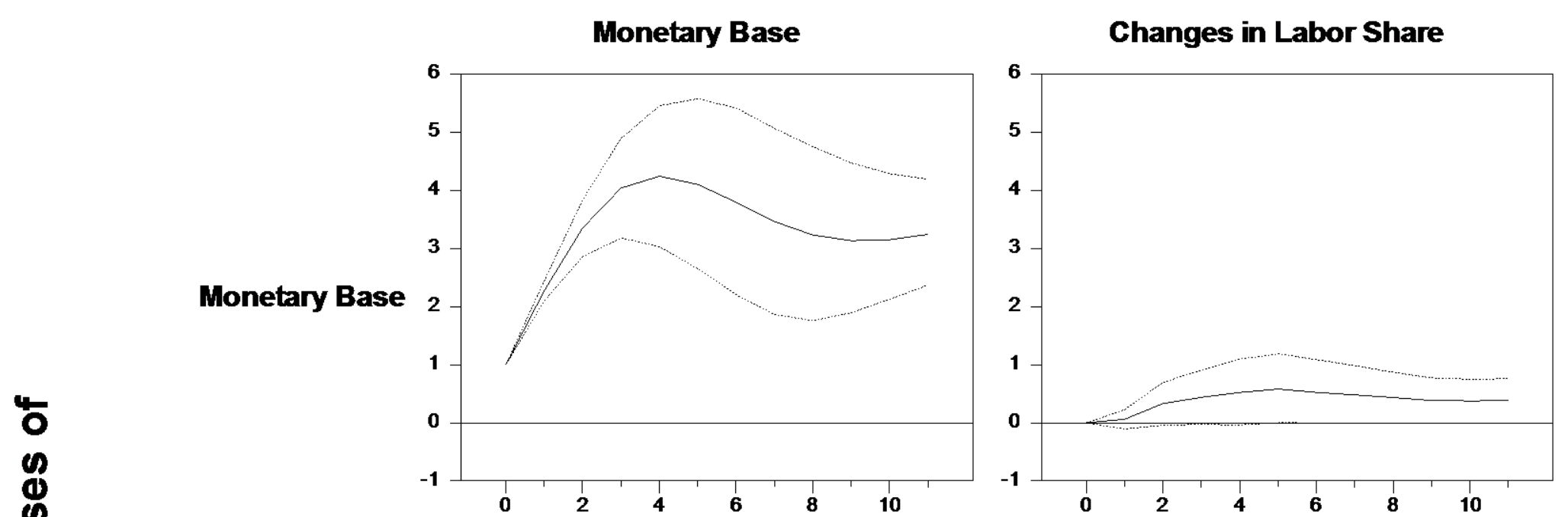

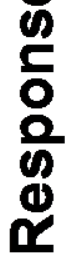

\section{Changes in Labor Share}
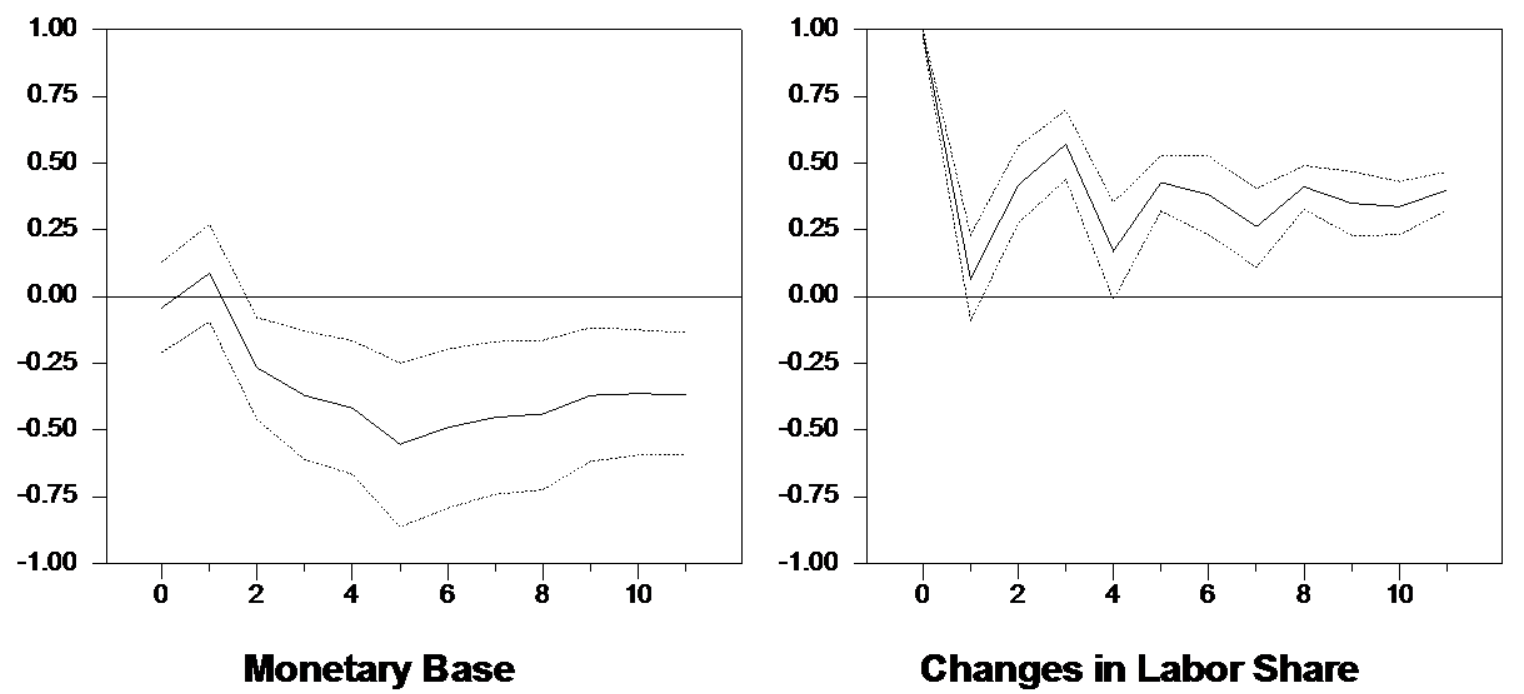
Figure 7. Cumulative Impulse Responses (Monetary Principal Component): 2008:Q3 - 2014
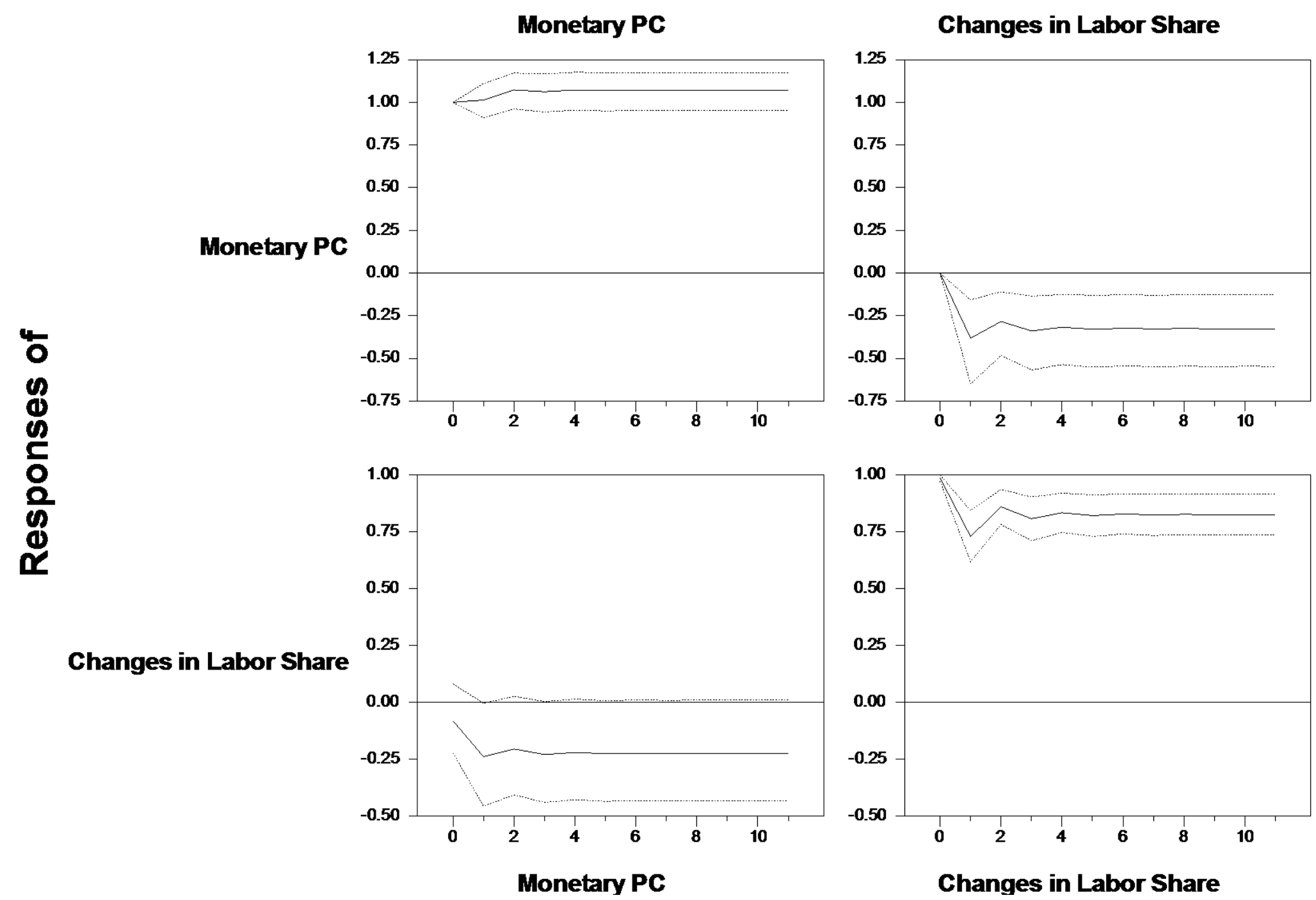